\title{
DINAMISASI HUKUM ISLAM DI INDONESIA PADA ZAKAT PRODUKTIF DAN WAKAF PRODUKTIF: SEBUAH STUDI PERBANDINGAN
}

\author{
Muslihun \\ IAIN Mataram \\ Jl. Pendidikan No. 35 Mataram \\ Email:muslih2009@yahoo.com
}

\begin{abstract}
Abstrak
Perbandingan zakat produktif dan wakaf produktif dapat dilihat dari lima hal, yakni dasar hukum, orang yang mengeluarkannya, jenisa hartanya, pengelolaannya, dan orang yang berhak menerimanya. Beberapa hal ini menunjukkan adanya persamaan di antara keduanya, yakni sama-sama merupakan filantropi Islam yang memiliki visi pemerataan harta. Walaupun demikian, terdapat perbedaan dalam hal: pertama, zakat bersifat wajib, sedangkan wakaf sunnah; kedua, harta zakat dapat didistribusikan secara langsung, sementara pada wakaf, yang dapat didistribusikan adalah hasilnya dan tidak boleh bendanya karena harus ditahan kelestariannya. Zakat produktif dan wakaf produktif dianggap sebagai bagian dari perubahan hukum Islam di Indonesia karena keduanya merupakan filantropi Islam yang senantiasa berkembang. Pergeseran zakat dan wakaf yang tadinya cendrung konsumtif menuju pola produktif merupakan buah dari perubahan sosial yang dipengaruhi oleh beberapa faktor: (1) perkembangan pembangunan fisik, (2) perubahan budaya, (3) pertumbuhan penduduk dan perkembangan teknologi baru, (4) adanya gerakan-gerakan sosial, dan (5) perubahan ide, nilai-nilai, dan pandangan hidup. Model perubahan sosial yang diharapkan adalah perubahan pemahaman zakat dan wakaf yang sebelumnya hanya konsumtif menjadi produktif. Dengan pengembangan zakat produktif diharapkan benda zakat mengalami peningkatan nilai. Sedangkan dengan pengembangan wakaf produktif diharapkan selain mempertahankan bendanya (dawām al-'ain) juga mempertahankan manfaat wakaf itu sendiri (dawām al-intifä' bi al-'ain).
\end{abstract}

Kata kunci: Zakat, Wakaf, Produktif, Dinamisasi, Manfaat, Profesionalisme

\begin{abstract}
The comparison between productive zakat and productive waqf can be viewed from five points, namely: their legal bases, zakat payers dan waqf givers, properties of zakat and waqf, zakat and waqf managers, and zakat dan waqf receivers. These points show the similarities between zakat and waqf in that both are parts of Islamic philanthropy. However, they also point to substantial differences between them. Firstly, zakat is obligatory, while waqf is not. Secondly, zakat can be distributed directly, while waqf can only be distributed of its benefits but not its property because the property must be preserved. Moreover, productive zakat and productive waqf are considered as parts of a dynamic change in Islamic law in Indonesia. The shifting patterns of zakat and waqf from consumptive towards productive trends is the fruit of social changes that are influenced by several factors, namely: (1) changes in physical development, (2) cultural changes, (3) population growth and development of new technology (4) the existence of social movements, and (5) changes in ideas, values, and worldview. The expected model of the social change is a change in understanding of zakat and waqf from consumptive to productive distributions. By developing zakat productively it is hoped that zakat gives a rise in terms of its values. Meanwhile by developing waqf productively it is hoped that it
\end{abstract}


will not only preserve its waqf property (dawām al-'ain) but also maintain its benefits (dawām al-intifä' bi al-'ain).

Keywords: Zakat, Waqf, Productive, Dynamic changes, Benefits, Professionalism

\section{A. Pendahuluan}

Zakat dan wakaf merupakan filantropi Islam yang sangat penting. Pembahasan tentang dua hal ini sangat intens dilakukan di kalangan umat Islam. Bahkan di Indonesia zakat dan wakaf ini telah dikeluarkan undang-undang yang mengaturnya secara formal, yakni UU No. 23 tahun 2011 tentang Pengelolaan Zakat dan UU No. 41 tahun 2004 tentang Wakaf.

Salah satu tema yang sangat penting dalam pembicaraan zakat dan wakaf ini adalah pengembangannya secara produktif. ${ }^{1}$ Upaya ini dianggap penting karena pengelolaan zakat dan wakaf secara konsumtif dianggap kurang berhasil dalam pengentasan kemiskinan umat Islam. Sebagai contoh, Umar bin Khattab pernah mengatakan bahwa tujuan zakat adalah dalam rangka mengubah seorang mustahiq (penerima zakat) menjadi muzakkiy (orang yang wajib mengeluarkan zakat). Ini berarti, zakat itu memiliki misi untuk menjadikan si miskin menjadi si kaya sehingga bisa menjadi seorang muzakkiy.

Demikian pula, pengelolaan wakaf selama ini banyak dinilai terlalu konsumtif, meskipun sudah ada upaya memproduktifkan wakaf tetapi masih dianggap belum maksimal. Berkaitan dengan pola pengembangan wakaf ini, $M$. Syafi'i Antonio melakukan pengelompokan menjadi tiga: pertama, periode tradisional, yakni wakaf masih ditempatkan pada ajaran yang murni (ibädah maḥ̣ah), seperti pembangunan fisik masjid dan mushalla. Kedua, periode semi-profesional, yakni pada masa ini sudah mulai dikembangkan pola pemberdayaan wakaf secara produktif. Contohnya, pembangunan masjid yang letaknya strategis dengan menambah bangunan gedung untuk pertemuan, pernikahan, dan seminar seperti masjid Sunda Kelapa. Ketiga, periode profesional, yakni periode yang ditandai dengan pemberdayaan potensi masyarakat secara produktif. Keprofesionalan yang dilakukan meliputi aspek: manajemen, SDM ke-nāzir-an, pola kemitraan usaha, dan lainnya. ${ }^{2}$

Aset-aset wakaf di atas perlu dikelola dengan produktif-profesional agar selaras dengan esensi wakaf dalam syariat Islam dan semangat UU No. 41 tahun 2004 tentang Wakaf. Pengelolaan wakaf dilakukan secara produktifprofesional harus dimulai dari bagaimana membangun paradigma wakaf yang dapat menyentuh ranah sosial. Hal ini dapat dilakukan dengan melihat peran tokoh agama dan masyarakat dalam mendorong perubahan paradigma itu. Oleh karena itu, perlu dinamisasi perubahan hukum Islam khususnya dalam masalah zakat dan wakaf ini agar benar-benar dapat tercapai tujuan pensyariatan (maqāsid) dari kedua institusi ini. Perubahan dalam dua hal ini merupakan suatu keniscayaan di tengah-tengah masyarakat yang selalu berubah dalam berbagai aspek kehidupan. $^{3}$

\section{B. Perubahan Hukum Islam pada Zakat dan Wakaf: Sebuah Keniscayaan \\ Perubahan hukum Islam} merupakan suatu keniscayaan ketika terjadi perubahan pada aspek yang lain, berupa perubahan situasi, kondisi, waktu, dan tempat. ${ }^{4}$ Sejak awal mula sejarah Islam, telah ada hubungan dialektis antara teks (nașs) dengan sejarah kemanusiaan dan antara teks dengan pemikiran manusia. Dengan demikian, sejarah dan pemikiran muslim merupakan hasil 
perpaduan yang kompleks antara yang bersifat "manusia" (human) dan yang bersifat "ketuhanan/keilahian" (divine); atau antara tulisan keagamaan (religious) dan faktor-faktor sosio-ekonomi dan politik. $^{5}$

Jika dilihat dari sisi bahwa tidak termasuk dalam rukun Islam yang lima maka wakaf termasuk ranah mu'āmalah (ibādah gair mahdah). Secara umum, kehidupan di dunia sekarang dapat dikelompokkan menjadi dua, yakni ranah ibadah mahdah (ibadah khusus) dan ranah ibādah gair mahduh (sosial). ${ }^{6}$ Persoalan mu'àmalat memiliki karakteristik berbeda dengan persoalan ibadah. Pada bidang ibadah, ajaran Islam dijelaskan secara tekstual bahkan dipraktikkan langsung oleh Nabi dan para sahabat, sedangkan hukum Islam bidang mu'āmalat biasanya dibahasakan secara umum oleh al-Qur'an. ${ }^{7}$ Karena kedua entitas ini memiliki perbedaan yang mendasar, maka kaidah Usuūl Fiqh tentang hal ini pun berangkat dari asumsi yang berbeda. Kalau pada persoalan ibadah, hukum dasarnya adalah haram kecuali ada dalil yang menjelaskan tentang adanya. ${ }^{8}$ Sementara pada persoalan mu'āmalah, hukum dasarnya adalah boleh sampai ada dalil (hukum) yang mengharamkannya. ${ }^{9}$

Berdasarkan uraian di atas, wakaf mestinya lebih bisa dikembangkan jika kita melihat ciri-ciri yang melekat pada ranah mu'āmalat. Pengembangan wakaf ini ternyata sering mengalami hambatan karena ada juga yang menganggap bahwa wakaf ini termasuk dalam ranah ibadah. Pendapat yang kedua ini rupanya hanya melihat dari sisi bahwa wakaf itu termasuk ranah tabarrū' (tolong menolong) dan jika melaksanakannya akan mendapatkan pahala.

Jika dilihat dari sisi akad, wakaf ini tergolong akad tabarrū' (tolong menolong), dan tidak termasuk pada akad bisnis atau akad in-between (antara keduanya) sebagaimana dapat dilihat dalam skema berikut ini:
Skema : 1

\section{Pengelompokan Akad dalam Khazanah Hukum Islam ${ }^{10}$}

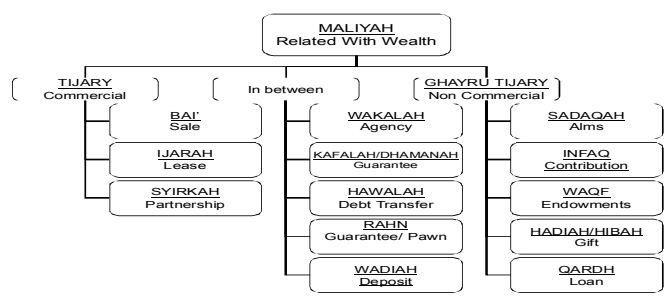

Ahmad Rofiq ${ }^{11}$ menegaskan bahwa fikih sebagai aktivitas penalaran manusia dalam mencoba memahami syari'ah, tentu sangat dipengaruhi oleh kapabilitas, sosio-kultural, dan sosiopolitik fäqih/fuqaha' ' yang bersangkutan. Munculnya perbedaan pendapat merupakan karakteristik fiqh yang tidak dapat dihindari. Karena itu, fiqh dapat mengandung multi-kebenaran, meskipun tidak terbatas dari sifat yang nisbi. Ini dapat dipahami dari sabda Rasulullah SAW. Yang diriwayatkan dari 'Amr bin 'As bahwa ia mendengar Rasulullah SAW bersabda, "Apabila seorang hakim memutuskan hukum dan ia berijtihad, kemudian ternyata ijtihadnya benar, maka ia mendapat dua pahala (pahala ijtihad dan pahala kebenarannya), dan jika ijtihadnya keliru maka ia mendapat satu pahala (pahala ijtihadnya)." (Musnad Ahmad bin Hanbal, 17148).

Berkaitan dengan ranah fiqh yang berbeda dengan syari'ah dilihat dari dapatnya menerima perubahan, lebih lanjut Ahmad Rofiq ${ }^{12}$ mengatakan:

"Fiqh sebagai hasil formulasi dari aktivitas penalaran manusia dalam memahami nașs al-Qur'an dan alSunnah, ia dapat-dan dalam batas tertentu sebagai keharusan-menerima perubahan dan pembaharuan, akibat perbedaan dan perubahan ruang dan waktu. Sebagai contoh klasik, Muhammad Idris al-Syafi'i (150204H/767-819M) dikenal mempunyai qawl qādim ketika beliau berada di Irak, dan setelah migrasi ke Mesir pendapatpendapatnya dikenal sebagai qawl jadìd. 
Malik bin Anas (95-179H/13-795M) yang hampir sepanjang hidup dihabiskan di Madinah, sering memiliki pendapat yang bervariasi dalam satu kasus hukum. Dari sinilah, hukum Islam memiliki elastisitas dan fleksibilitas yang tinggi, dibangun atas dasar universalitas syari'ah yang cocok untuk segala situasi dan tempat."

Secara sosiologis, menurut Satjipto Rahardjo, perubahan sosial merupakan ciri yang melekat dalam masyarakat. Hal ini disebabkan masyarakat itu mengalami suatu perkembangan. Karena itu, perkembangan tersebut perlu direspons juga oleh hukum Islam yang pada gilirannya hukum Islam diharapkan memiliki kemampuan fungsi sebagai social engineering selain sebagai social control, atau meminjam istilah T. Mulya Lubis, selain hukum sebagai repressive laws ia juga sanggup menjadi fasilitative laws. ${ }^{13}$

\section{Perbandingan Konsep Zakat Produktif dan Wakaf Produktif di Indonesia}

Untuk membandingkan zakat produktif dan wakaf produktif dapat dilihat dari konsep keduanya sehingga terlihat perbedaan antara keduanya.

1. Konsep Zakat Produktif dan Wakaf Produktif

Zakat produktif merupakan zakat yang dikelola oleh amil zakat secara produktif, khususnya pada pemanfaatan (tasarruf) zakat kepada para mustahiq zakat. Istilah zakat produktif muncul dari adanya kendala optimalisasi zakat di tengah-tengah masyarakat. UU zakat telah mengisyaratkan agar zakat didayagunakan secara produktif. Hal ini dapat dilihat dalam Pasal 27 yang berbunyi "Zakat dapat didayagunakan untuk usaha produktif dalam rangka penanganan fakir miskin dan peningkatan kualitas umat."14 Fungsi konsumtif dipandang sebagai salah satu pandangan tradisional yang perlu disempurnakan. Untuk mensejahterakan para mustahiq dalam rentang waktu yang lebih lama. Maka sangat manusiawi untuk dipikirkan pendayagunaan zakat yang tidak hanya berbasis konsumtif belaka. Tentang pendayagunaan zakat, zakat itu mempunyai dua fungsi utama. Pertama, untuk membersihkan harta benda dan jiwa manusia. Kedua, zakat berfungsi sebagai dana masyarakat. Pemanfaatan zakat dapat dikategorikan menjadi empat, yaitu konsumtif tradisional (keperluan makan), konsumtif kreatif (berbentuk alat-alat sekolah, beasiswa), produktif tradisional (berbentuk barang-barang produktif), produktif kreatif (berbentuk modal untuk berdagang). ${ }^{15}$

Sementara, wakaf produktif terdiri dari dua kata, yakni wakaf dan produktif. Wakaf secara harfiah bermakna "pembatasan" atau "larangan". Sedangkan secara istilah, wakaf didefinisikan secara beragam. ${ }^{16}$ Definisi yang tertuang dalam UU No. 41 tahun 2004 tentang Wakaf juga mengadopsi pendapat jumhur ulama, yakni wakaf adalah perbuatan hukum wakif (pemberi wakaf) untuk memisahkan dan/atau menyerahkan sebagian harta benda miliknya untuk dimanfaatkan selamanya atau untuk jangka waktu tertentu sesuai dengan kepentingannya guna keperluan ibadah dan/atau kesejahteraan umum menurut syari'ah (Pasal 1 ayat 1).

Sementara, kata produktif itu sendiri adalah kata sifat dari wakaf. Abdullah Sa'ad al-Hajiri ${ }^{17}$ mengajukan definisi produktif sebagai berikut: "Produktif adalah suatu pengorbanan dengan harga terbaru yang telah ditetapkan dan pengembangan (investasi)-nya dilakukan dengan mendapatkan hasil yang bernilai lebih tinggi tanpa penetapan pada masa yang akan datang."

Jaih Mubarok ${ }^{18}$ mendefinisikan wakaf produktif sebagai transformasi dari pengelolaan wakaf yang alami menjadi pengelolaan wakaf yang profesional 
untuk meningkatkan atau menambah manfaat wakaf. Bisa juga wakaf produktif diartikan sebagai proses pengelolaan benda wakaf untuk menghasilkan barang atau jasa yang maksimum dengan modal yang minimum. Sementara, menurut Monzer Qahaf, ${ }^{19}$ wakaf produktif adalah:

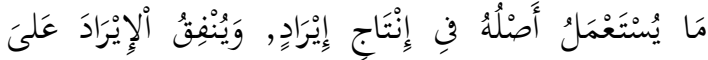

$$
\begin{aligned}
& \text { غَرَضِ ألَوقَفِْ. }
\end{aligned}
$$

"Harta wakaf yang digunakan untuk kepentingan produksi, harta wakaf dikelola untuk menghasilkan barang dan jasa kemudian dijual dan hasilnya dipergunakan sesuai dengan tujuan wakaf."

\section{Tolhah $\operatorname{Hasan}^{20}$ menjelaskan} bahwa wakaf produktif adalah wakaf yang dapat memberikan hasil dalam nilai ekonomis, seperti pertanian atau perkebunan, ruko yang disewakan, rumah untuk budidaya burung walet, rumah sakit, dan lain-lain. Wakaf produktif, tandasnya, dibedakan dengan wakaf konsumtif, dalam arti barang-barang wakaf yang tidak menghasilkan sesuatu yang mempunyai nilai ekonomis.

Dengan demikian, istilah wakaf produktif merupakan istilah yang muncul belakangan seiring dengan kesadaran perlunya optimalisasi pengelolaan harta wakaf, meskipun produktivitas itu merupakan essensi wakaf. Sehingga wakaf produktif menghendaki pengelolaan secara optimal agar menghasilkan keuntungan secara ekonomi yang akan digunakan untuk kesejahteraan umat. Pandangan ini dapat pula ditemukan dalam penjelasan pasal 43 ayat (2) UU No. 41 tahun 2004 tentang Wakaf. ${ }^{21}$

Wakaf adalah salah satu instrumen ekonomi Islam yang sangat potensial dalam meningkatkan kesejahteraan sosial. Ia dapat memiliki peran yang sangat besar dalam membantu menyelesaikan masalah sosial ekonomi masyarakat jika dikelola secara profesional dan produktif. Namun, selama ini harta benda wakaf masih dikelola secara tidak produktif karena wakaf hanya dipahami oleh mayoritas umat Islam Indonesia sebagai amalan ibadah semata (mahdah) yang tidak memiliki dimensi ekonomi ataupun dimensi sosial. ${ }^{22}$

Oleh karena itu, esensi wakaf adalah keberlanjutan. Wakaf harus dikembangkan atau diproduktifkan agar memiliki manfaat yang maksimal dan terus menerus. Secara teori, jika disandarkan pada hadis Umar r.a. tentang wakaf, $^{23}$ maka wakaf berarti "wakaf produktif".

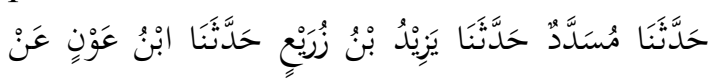

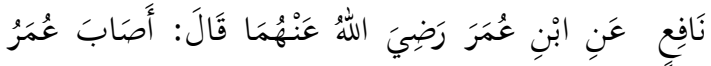

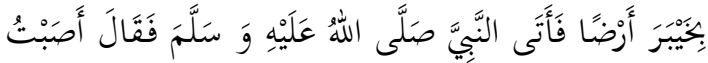

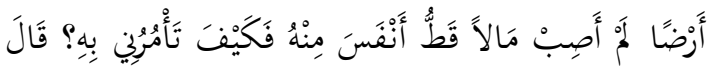

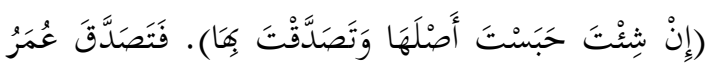

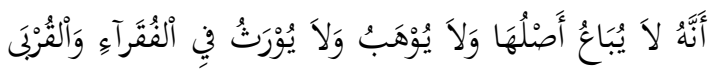

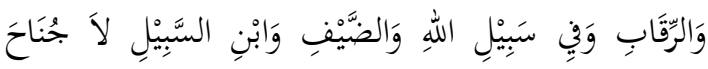

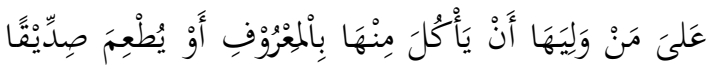
غَيْرَ مُتَمَوَّلِ فِيِْه.

Sementara, jika dilihat dari praktek pengelolaan wakaf yang ada di Indonesia, misalnya, maka wakaf tetap dapat dikelompokkan menjadi wakaf produktif dan wakaf tidak produktif (konsumtif karena digunakan untuk kebutuhan yang tidak menghasilkan nilai tambah secara ekonomi). Bisa juga dikatakan bahwa wakaf yang tidak produktif atau terbengkalai itu merupakan wakaf yang keluar dari substansi hadis Umar r.a. di atas.

Jika dilihat dari pengembangan aset wakaf, maka wakaf dapat dibagi menjadi pengembangan secara produktif dan pengelolaan sumbangan. Sedangkan jika dilihat dari sisi penyaluran atau pemanfaatan aset wakaf, dapat pula dibagi menjadi dua, yakni pemanfaatan secara produktif dan pemanfaatan secara konsumtif. 
2. Perbedaan Zakat Produktif dan Wakaf Produktif

Untuk melihat perbedaan zakat produktif dan wakaf produktif dapat dilihat dari perbedaan antara zakat dan wakaf itu sendiri, karena tambahan "produktif" sesungguhnya berangkat dari konsep awal dari zakat dan wakaf itu sendiri. Perbedaan zakat dan wakaf dapat dilihat dari lima hal, yakni dasar hukum, wāqif dan muzakkiy, hartanya (mauqūf bih dan māl al-zakāt), pengelola (nāzir dan 'àmil), yang berhak menerima (mauqūf 'alaih dan mustahiq). ${ }^{24}$

Pertama, dasar hukum. Secara dasar hukum antara zakat dan wakaf sangat berbeda. Zakat merupakan ajaran Islam yang ditempatkan sebagai salah satu ajaran Islam yang qaț'i al-dalālah (jelas atau pasti penunjukkan lafaznya). Walaupun harus diakui bahwa dalam banyak hal, dalam teknis operasional zakat banyak sekali mengalami inovasi sebagai upaya pemberdayaan sesuai keadaan yang ada. Sementara, dasar hukum wakaf sangat jarang disebutkan baik dalam nass al-Qur'an maupun Hadis.

Kedua, wāqif dan muzakkī. Wāqif sebagai subyek wakaf memiliki otoritas penuh terhadap harta yang ingin diwakafkan. Karena sifatnya yang lentur dan bebasnya kehendak para wakif, maka calon wakif harus memiliki persyaratanpersyaratan agar sah wakafnya, yakni memiliki kecakapan hukum (kamāl alahliyah/legal competence) dalam membelanjakan hartanya. Kecakapan berinfak ini meliputi empat kriteria, yakni merdeka, berakal sehat, dewasa (bāligh), tidak berada di bawah pengampuan (boros/lalai).

Sedangkan orang yang menunaikan zakat (muzakkī) memiliki kedudukan yang sama seperti wakif dalam wakaf. Yang membedakan secara mencolok adalah aspek hukumnya. Kalau zakat didasarkan pada kemampuan (kepemilikan) atas harta dalam kadar tertentu untuk dikeluarkan sebagiannya yang bertujuan untuk membersihkan harta secara batiniyah yang berhukum wajib, maka wakaf dijalankan setelah melaksanakan ibadah zakat sebagai bentuk perbuatan hukum yang bersifat sunnah. Orang yang wajib zakat belum tentu akan berwakaf, sedangkan orang yang berwakaf sudah tentu sudah harus melakukan zakat.

Pelaksanaan zakat bagi muzakki bersifat otoritatif ( $i j b \bar{a} r i)$ yang melibatkan pihak kekuasaan. Oleh karena itu, pelaksanaan zakat tidak saja dipertanggungjawabkan secara individu, tetapi juga kepada pemerintah. Sedangkan wakaf bersifat sukarela dan tidak ada pihak yang harus dipertanggungjawabkan atas perintah pelaksanaannya. $^{25}$

Dari segi gagasan fundamental, sebenarnya wakaf memiliki kesamaan visi dengan zakat, yaitu terjadinya pemerataan keadilan ekonomi. Namun yang membedakannya adalah filosofi hukum dan titik tekan atau arah pemberdayaannya. Zakat adalah unsur pembersihan harta muzakki yang dimiliki untuk dibagikan kepada delapan așnāf, sedangkan wakaf merupakan unsur penambahan amal kebajikan yang berdimensi kontinuitas pahala dalam rangka peningkatan kesejahteraan masyarakat.

Dari segi keterkaitan dengan ikrar, wakif membutuhkan ikrar sebelum yang bersangkutan melaksanakan wakaf, sedangkan muzakki tidak memerlukan ikrar karena pelaksanaan zakat sifatnya ijbār $\bar{i}$ (memaksa), tanggungjawab pengelolaannya diserahkan kepada amil yang dibentuk oleh pemerintah. Namun arah dari keduanya mengerucut kepada pemerataan kesejahteraan ekonomi. ${ }^{26}$

Ketiga, mauqūf bih dan māl alzakāt. Mauqūf bih (harta wakaf) adalah benda yang diwakafkan. Harta yang diwakafkan itu bisa dipandang sah apabila memenuhi syarat sebagai berikut: (1) benda harus memiliki nilai guna, (2) benda tetap atau benda bergerak yang dibenarkan untuk diwakafkan. Alasan 
yang sering disampaikan oleh golongan Syafiiyah adalah agar harta wakaf itu terjaga kekekalan fungsi atau manfaat harta; (3) benda yang diwakafkan harus tertentu (diketahui) ketika terjadi akad wakaf. Penentuan benda tersebut bisa ditetapkan dengan jumlahnya, seperti seratus juta rupiah; (4) benda yang diwakafkan banar-benar telah menjadi milik sempurna (al-milk al-tāmm) si wakif. Maka tidak sah mewakafkan harta yang masih dalam sengketa atau menjadi jaminan. $^{27}$

Sementara māl al-zakāt adalah jenis-jenis tertentu dari harta yang harus dikeluarkan zakatnya. Al-Qur'an memang tidak merincinya secara eksplisit, namun al-Qur'an hanya menggunakan lafaz umum, yaitu amwāl yang bermakna segala macam jenis harta, meskipun dalam hadis Nabi telah disebutkan beberapa nama dan jenis harta yang wajib dizakati seperti al-masyiyah (beberapa jenis hewan).

Keempat, pengelola (nāzir dan 'āmil). Walaupun para mujtahid tidak menjadikan nāẓir sebagai salah satu rukun wakaf, para ulama sepakat bahwa wakif harus menunjuk nāzir wakaf, baik yang bersifat perseorangan maupun kelembagaan (badan hukum). Persyaratan nāzir wakaf sebagai berikut: (1) syarat moral, seperti paham tentang hukum wakaf dan ZIS dan jujur; (2) syarat manajemen, seperti mempunyai kapasitas dan kapabilitas yang baik dalam leadership, profesional dalam bidang pengelolaan harta; (3) syarat bisnis, seperti mempunyai keinginan, mempunyai ketajaman melihat peluang usaha.

Sementara, amil zakat adalah pengelola harta zakat. Menurut Yusuf Qardhawi, seorang amil zakat harus memiliki persyaratan sebagai berikut:
Islam, mukallaf, amanah dan jujur, mengerti dan memahami hukum-hukum zakat yang menyebabkan ia mampu melakukan sosialisasi, memiliki kemampuan untuk melaksanakan tugas, kesungguhan amil dalam bertugas. Sedangkan berdasarkan Keputusan Menteri Agama RI No. 581 tahun 1999, syarat lembaga zakat sebagai berikut: Berbadan hukum, memiliki data muzakki dan mustahiq, memiliki program kerja yang jelas, memiliki pembukuan yang baik, melampirkan surat pernyataan bersedia diaudit.

Kelima, penerima wakaf dan zakat (mawqūf 'alaih dan mustahiq). Mawqūf 'alaih (penerima wakaf) adalah orangorang yang menerima wakaf. Pada dasarnya wakaf merupakan amal yang mendekatkan diri manusia kepada Tuhan. Karena itu, mawqūf 'alaih harus pihak kebajikan. Selanjutnya, selain istilah mauqūf 'alaih, peruntukan wakaf dalam bahasa Arab juga menggunakan istilah istihqua al-waqf. Mawqūf 'alaih dapat diartikan sebagai sasaran atau pihak yang menerima wakaf. ${ }^{28}$ Dalam hal distribusi wakaf, aturan syariah tidak begitu jelas dan tegas. Hal ini berbeda dengan zakat yang distribusinya harus diarahkan pada așnāf al-samāniyah.

Sementara, mustahiq al-zakāt adalah mereka yang berhak menerima zakat. Penerima zakat ini telah ditentukan secara tegas dalam Qs. al-Taubah (9): 60, yakni delapan kelompok (așnāf alśamāniyah), yaitu faqir, miskin, amil, mu'allaf, riqāb, gārimin, fì sabīlillāh, dan ibnu sabīl. Dari kedelapan așnāf tersebut, faqir miskin paling awal disebut karena mereka adalah kelompok sosial dalam masyarakat yang paling lemah dan harus mendapatkan perhatian serius dari para pemilik harta. 
Untuk memperjelas perbedaan dan persamaan antara zakat dan wakaf, dapat dilihat dalam tabel berikut ini:

Tabel:1

Perbandingan Zakat dan Wakaf

\begin{tabular}{|c|c|c|c|c|}
\hline \multirow{2}{*}{$\begin{array}{l}\mathbf{N} \\
\mathbf{O}\end{array}$} & \multirow{2}{*}{$\begin{array}{c}\text { ASPEK- } \\
\text { ASPEKNYA }\end{array}$} & \multicolumn{2}{|c|}{ PERBEDAAN } & \multirow{2}{*}{ PERSAMAANNYA } \\
\hline & & ZAKAT & WAKAF & \\
\hline 1 & $\begin{array}{l}\text { Dasar } \\
\text { hukumnya }\end{array}$ & Tegas dan jelas dalam nașs & $\begin{array}{l}\text { Tidak Tegas dan Jelas } \\
\text { dalam nașs }\end{array}$ & $\begin{array}{l}\text { Sama-sama punya } \\
\text { dasar hukum }\end{array}$ \\
\hline 2 & $\begin{array}{l}\text { Muzakkī dan } \\
\text { Wāqif }\end{array}$ & $\begin{array}{l}\text { Muzakkï-nya wajib } \\
\text { mengeluarkan zakat jika telah } \\
\text { memenuhi syarat } \\
\text { Muzakki tidak bisa } \\
\text { menentukan syarat-syarat } \\
\text { tertentu kecuali sesuai dengan } \\
\text { ketentuan syarak }\end{array}$ & $\begin{array}{l}\text { Wakif-nya mengeluarkan } \\
\text { wakaf hanya karena } \\
\text { anjuran (sunnat) } \\
\text { Wakif dapat menentukan } \\
\text { syarat-syarat asal tidak } \\
\text { bertentangan dengan } \\
\text { syarak }\end{array}$ & $\begin{array}{l}\text { Sama-sama } \\
\text { mengeluarkan harta } \\
\text { untuk kepentingan } \\
\text { kebajikan }\end{array}$ \\
\hline 3 & $\begin{array}{l}\text { Māl al-Zakāt } \\
\text { dan Mawquf } \\
\text { bih }\end{array}$ & $\begin{array}{l}\text { Harta zakat boleh dibagikan } \\
\text { langsung harta zakatnya }\end{array}$ & $\begin{array}{l}\text { Harta wakaf tidak boleh } \\
\text { dibagikan langsung harta } \\
\text { wakafnya, kecuali } \\
\text { hasilnya saja (samrah al- } \\
\text { waqf) }\end{array}$ & $\begin{array}{lr}\text { Sama-sama } & \text { dapat } \\
\text { dinikmati } & \text { bahkan } \\
\text { dimiliki oleh pihak } \\
\text { yang } & \text { berhak } \\
\text { menerima } & \end{array}$ \\
\hline 4 & $\begin{array}{l}\text { Amil dan } \\
\text { Nāzịir }\end{array}$ & $\begin{array}{l}\text { Amil secara tegas disebutkan } \\
\text { dalan nașs al-Qur'an (at- } \\
\text { Taubah: 60) }\end{array}$ & $\begin{array}{l}\text { Nāzir bukan merupakan } \\
\text { rukun dari wakaf }\end{array}$ & $\begin{array}{l}\text { Sama-sama } \\
\text { memerlukan } \\
\text { pengelola agar dapat } \\
\text { terdistribusi dengan } \\
\text { baik sesuai syar } \bar{a} \text {, }\end{array}$ \\
\hline 5 & $\begin{array}{l}\text { Mustahiq } \\
\text { dan Mauqūf } \\
\text { 'Alaih }\end{array}$ & $\begin{array}{l}\text { Sasaran zakat sudah pasti pada } \\
\text { delapan kelompok (asnäf al- } \\
\text { samāniyah) }\end{array}$ & $\begin{array}{lc}\text { Sasaran } & \text { wakaf ditujukan } \\
\text { kepada kebajikan dan } \\
\text { lebih luas } \\
\text { peruntukan zakat }\end{array}$ & $\begin{array}{l}\text { Sama-sama untuk } \\
\text { kebajikan }\end{array}$ \\
\hline
\end{tabular}

\section{Konsep Zakat Produktif dan Wakaf Produktif dalam Perundang-Undangan}

1. Konsep Zakat Produktif dalam UU No. 21 Tahun 2011

Dalam UU No. 21 tahun 2011 tentang Pengelolaan Zakat dijelaskan tentang pengelolaan zakat pada pasal 2 dan 3. Sementara, pengelolaan secara produktif secara lebih khusus dijelaskan pada 25, 26, dan 27.

Pasal 2 mengisyaratkan bahwa zakat selain harus dikelola sesuai syariat Islam, juga harus dikelola dengan prinsipprinsip lainnya, yakni amanah, kemanfaatan, keadilan, kepastian hukum, terintegrasi, dan akuntabilitas. Prinsipprinsip ini terintegrasi dalam rangka mencapai tujuan yang diidealkan sebagaimana isi Pasal 3, yakni (a) meningkatkan efektivitas dan efisiensi pelayanan dalam pengelolaan zakat; dan (b) meningkatkan manfaat zakat untuk mewujudkan kesejahteraan masyarakat dan penanggulangan kemiskinan. Tujuan yang sangat ideal di Pasal 3 di atas akan dapat tercapai jika zakat dikelola secara produktif sebagaimana yang dapat dipahami dari pasal berikutnya, yakni Pasal 27.

Terlaksananya pengelolaan zakat secara produktif tidak lepas dari semangat besar dalam UU No. 23 tahun 2011. Salah satu gagasan besar penataan pengelolaan zakat yang tertuang dalam UU No. 23 tahun 2011 tersebut dan yang menjiwai keseluruhan pasalnya adalah pengelolaan yang terintegrasi. Kata "terintegrasi" menjadi asas yang melandasi kegiatan pengelolaan zakat di negara kita, baik dilakukan Badan Amil Zakat Nasional (BAZNAS) di semua tingkatan maupun Lembaga Amil Zakat 
(LAZ) yang mendapat legalitas sesuai ketentuan perundang-undangan. ${ }^{29}$

Integrasi pengelolaan zakat menempatkan BAZNAS sebagai koordinator. Peran koordinator merupakan satu kesenyawaan dengan integrasi. Pengkoordinasian yang dilakukan BAZNAS inilah yang ke depan akan mengawal jalannya proses integrasi dan sinergi dari sisi manajemen maupun dari sisi kesesuaian syariah. Hal ini diatur dalam ketentuan Pasal 6 dan 7 UU No. 23 tahun 2011 sebagai dasar hukum yang memberikan ruang terbuka kepada BAZNAS untuk menjalankan fungsi koordinasi. Ketika LAZ menjadi bagian dari sistem yang dikoordinasikan BAZNAS, maka posisinya secara hukum menjadi kuat, sehingga prinsip dan tuntunan syariah dalam al-Qur'an (QS. al-Taubah 9: 103 dan 60) dapat terpenuhi. $^{30}$

Para pengelola zakat perlu memahami lahirnya UU No. 23 tahun 2011 tentang Pengelolaan Zakat yang akan dilengkapi dengan Peraturan Pemerintah tentang Pelaksanaan undangundang. Pemahaman tersebut sejatinya bertujuan untuk menata pengelolaan zakat agar lebih baik. Penataan sebagaimana dimaksud tidak terlepas dari kepentingan untuk menjadikan amil zakat lebih profesional, memiliki legalitas secara yuridis formal dan mengikuti sistem pertanggungjawaban kepada pemerintah dan masyarakat. Tugas dan tanggung jawab sebagai amil zakat tidak bisa dilepaskan dari prinsip syariah yang mengaitkan zakat dengan kewenangan pemerintah (ulil amri) untuk mengangkat amil zakat.

2. Konsep Wakaf Produktif dalam UU No. 41 Tahun 2004

Pengaturan Wakaf Produktif dalam UU No. 41 tahun 2004 terdapat dalam Bab $\mathrm{V}$ tentang pengelolaan dan pengembangan harta benda wakaf, khususnya Pasal 42 sampai pasal 44 . Pada Pasal 42 UU wakaf di atas secara tegas mengatakan bahwa nazir wajib mengelola dan mengembangkan harta benda wakaf sesuai dengan tujuan, fungsi, dan peruntukannya. Ini artinya apa yang dihajatkan oleh nāzir harus menjadi rujukan utama bagi para nāzir dalam mengelola wakaf. Sehingga dalam konteks ini sangat berkorelasi dengan kaidah ușūl yang mengatakan: "Niyyat alwāqif ka nașs al-syar'i" (tujuan wakif sama kedudukannya dengan ketentuan syara' itu sendiri). Hal ini dipertegas lagi dalam Pasal 44 ayat (2) yang berbunyi: "Izin sebagaimana dimaksud pada ayat (1) hanya dapat diberikan apabila harta benda wakaf ternyata tidak dapat dipergunakan sesuai dengan peruntukan yang dinyatakan dalam ikrar wakaf."

Pasal 43 UU wakaf ini juga menegaskan tiga hal, yakni wakaf harus dikelola dengan prinsip syariah (ayat (1)), lalu dalam ayat (2) dijelaskan bahwa wakaf yang dimaksud dalam ayat 1 dikembangkan secara produktif. Kemudian dalam rangka menjamin pengelolaan wakaf secara produktif diperlukan lembaga penjamin yang dapat menjamin keutuhan atau keabadian harta wakaf.

Persoalan yang sering muncul berkaitan dengan pengembangan wakaf dan zakat produktif ini adalah kurangnya sosialisasi, khususnya wakaf produktif. Sosialisasi pemerintah lewat Kementerian Agama RI tentang wakaf produktif sebagaimana dimuat dalam UU No. 41 tahun 2004 tentang Wakaf merupakan upaya positif bagi pengembangan wakaf produktif di Indonesia. Sosialisasi ini harus dilakukan secara berkesinambungan dengan melibatkan stake holders daerah yang ada. Dengan mengaitkan wakaf produktif dengan sosialisasi zakat produktif, TGH. Syamsul Hadi mengatakan bahwa pengembangan wakaf produktif ini memang sejalan dengan semangat dari wakaf produktif yang ada dalam UU wakaf. Sejalan pula dengan pengembangan zakat produktif yang digalakkan oleh pemerintah. Kalau 
dahulu dalam berzakat langsung diberikan beras untuk kebutuhan makan, sekarang diberikan "pancingnya". Diberikan modal usaha agar dapat menghasilkan pendapatan untuk hidup. ${ }^{31}$

TGH. Hasanain berpandangan bahwa wakaf produktif ini hanya berkaitan dengan persoalan manajemen mengatur harta umat bukan hukum harta umat. Oleh karena itu, ia menegaskan bahwa selama konsep wakaf produktif itu diterima dan tidak menzalimi siapapun maka tidak ada masalah untuk dipraktekkan. Apalagi, pengelolaan wakaf dengan produktif memiliki esensi untuk menjaga keberlangsungan manfaat wakaf itu sendiri. Hal ini diilustrasikan dengan harta anak yatim. Dalam alQur'an dijelaskan bahwa tidak boleh diberikan hartanya kalau anak yatim itu tidak mampu mengelolanya sendiri. Ayat ini menegaskan bahwa orang lain harus mengelola harta anak yatim tersebut secara profesional baru setelah sampai berusia dewasa (mampu) baru diberikan mengelola hartanya sendiri. Lebih-lebih lagi harta wakaf itu adalah harta umat, tentu harus dikelola secara profesional lebih dahulu baru didistribusikan. ${ }^{32}$

\section{E. Zakat Produktif dan Wakaf Produktif dalam Konteks Dinamisasi Hukum Islam}

Zakat produktif dan wakaf produktif merupakan dua filantropi Islam yang senantiasa mengalami perkembangan dari masa ke masa. Istilah produktif dalam kedua filantropi tersebut sebenarnya bukan merupakan sesuatu yang asing dan sangat baru. Zakat misalnya, jika dilihat dari sisi etimologinya memang berarti berkembang dan bertambah. Sehingga ketika dalam konteks sekarang ini adalah istilah zakat produktif sesungguhnya hanya bersifat penegasan kembali bahwa esensi zakat itu harus dikembangkan bukan saja agar sampai kepada para mustahiq tetapi juga seyogyanya disalurkan dengan misi produktivitas agar semangat awal dari zakat itu benar-benar dapat terealisasi dengan baik.

Terlebih lebih lagi wakaf, institusi ini bahkan memiliki semangat utama untuk dikembangkan karena yang bisa didistribusikan hanya hasil dari produktivitas itu sesuai dengan makna hadis Umar yang substansinya pada kalimat "Ihbis aṣlahā wa tasaddaq samrataha " (tahanlah asalnya dan bagikanlah hasilnya).

\section{Zakat Produktif}

Penyaluran zakat secara produktif pernah terjadi di zaman Rasulullah SAW. Hadis riwayat Imam Muslim dari Salim bin Abdillah bin Umar dari ayahnya, bahwa Rasulullah telah memberikan zakat kepadanya lalu menyuruhnya untuk dikembangkan atau disedekahkan lagi. Disyaratkan bahwa yang berhak memberikat zakat produktif adalah yang mampu melakukan pembinaan dan pendampingan kepada para mustahiq agar kegiatan usahanya dapat berjalan dengan baik.

Dengan demikian, dapat dipahami bahwa zakat produktif ini berada pada ranah pemanfaatan zakat. Model zakat produktif ini pernah dipraktekkan di beberapa tempat seperti di Kendal Jawa Tengah. Pemberian zakat secara produktif ini adalah bentuk kebijakan dari pengelolaan zakat profesi yang dikelola di Kendal Jawa Tengah. Menurut KH. Drs. Asmawi Usman, penerapan zakat profesi di Kabupaten Kendal ini meski tidak dijadikan sebagai PERDA, terbukti banyak membantu kaum fakir-miskin. Bahkan motivasi utama dari program ini, lanjutnya, dalam rangka memberikan contoh yang baik (uswatun hasanah) dan menumbuhkan kesadaran para PNS/abdi negara dalam membantu kaum fakirmiskin dengan cara memberikan (mentasarruf-kan) zakat tersebut dalam bentuk yang produktif, seperti membelikan becak. $^{33}$

Pengelolaan zakat secara produktif sangat menghajatkan pengelola (āmil) yang profesional. Pelaksanaan 
ibadah zakat melibatkan sejumlah kegiatan yang berkaitan dengan pengelolaan harta benda, sejak pengumpulan, pendistribusian, pengawasan, pengadministra-sian, dan pertanggungjawaban harta zakat. Untuk terlaksananya ibadah zakat sesuai dengan ketentuan agama, maka mutlak diperlukan pengelolaan (manajemen) zakat yang benar dan profesional. ${ }^{34}$

2. Wakaf Produktif

Menurut Mustafa Edwin Nasution dan Uswatun Hasanah, ${ }^{35}$ wakaf adalah salah satu instrumen ekonomi Islam yang sangat potensial dalam meningkatkan kesejahteraan sosial. Ia dapat memiliki peran yang sangat besar dalam membantu menyelesaikan masalah sosial ekonomi masyarakat jika dikelola secara profesional dan produktif. Namun, selama ini harta benda wakaf masih dikelola secara tidak produktif karena wakaf hanya dipahami oleh mayoritas umat Islam Indonesia sebagai amalan ibadah semata (mahdah) yang tidak memiliki dimensi ekonomi ataupun dimensi sosial.

Dengan

memberdayakan wakaf produktif ${ }^{36}$ maksudnya mengelola wakaf secara profesional dan bertanggungjawab sehingga menghasilkan wakaf yang memiliki makna sosial dan memiliki beragam manfaat (multiplier effect), yakni manfaat rohani dan manfaat fisik. Dari manfaat tersebut kemudian diperoleh keabadian manfaat atau manfaat yang lebih tinggi, profesionalisme manajemen, pertanggungjawaban, keadilan sosial, dan kerjasama antar umat.

Pengelolaan wakaf secara produktif ini secara hukum merupakan amanat dari UU wakaf. Itulah sebabnya UU No. 41 tahun 2014 dianggap sebagai awal mula paradigma baru wakaf di Indonesia oleh Kemenag RI. Jaih Mubarok juga menegaskan bahwa UU No. 41 tahun 2004 ini memiliki paradigma baru wakaf karena dalam UU ini mempertegas bahwa wakaf itu memiliki dimensi sosial atau paradigma ibadah sosial. ${ }^{37}$

\section{F. Bentuk-Bentuk Perubahan Sosial dari Pengembangan Zakat Produktif dan Wakaf Produktif}

Perubahan-perubahan pada masyarakat dewasa ini merupakan gejala yang normal, pengaruhnya dengan cepat menjalar ke seluruh pelosok dunia berkat adanya komunikasi modern. Penemuanpenemuan baru di bidang teknologi, terjadinya suatu revolusi, modernisasi pendidikan, dan seterusnya di suatu tempat, dengan cepat dapat diketahui masyarakat yang jauh letaknya. Perubahan-perubahan dalam masyarakat dapat mengenai nilai sosial, kaidahkaidah sosial, pola-pola prilaku, organisasi, susunan lembaga kemasyarakatan, lapisan-lapisan dalam masyarakat, kekuasaan dan wewenang, interaksi sosial, dan lain sebagainya. ${ }^{38}$

Sebagaimana layaknya sebuah pemikiran atau hasil ijtihad manusia, zakat dan wakaf juga menghasilkan perubahan sosial karena ada upaya untuk merevitalisasi kedua institusi itu, yakni dari zakat dan wakaf yang dikelola secara konsumtif menuju zakat dan wakaf yang dikelola secara produktif. Dengan demikian, perubahan sosial yang diharapkan adalah terwujudnya pemahaman yang sama di antara umat Islam tentang pentingnya pengelolaan zakat dan wakaf secara produktif, sehingga memiliki nilai manfaat yang lebih besar bagi masyarakat luas. 
Berikut ini adalah skema perubahan yang terjadi pada pengelolaan zakat konsumtif ke zakat produktif:

Tabel : 2 .

Makna Perubahan Zakat dari Konsumtif ke Produktif

\begin{tabular}{|c|c|c|c|}
\hline HAL & \multicolumn{2}{|c|}{ PERUBAHANNYA } & KETERANGAN \\
\hline Bentuk & $\Delta$ & D & - A (Konsumtif) \\
\hline Dalam Perspektif & $\begin{array}{l}\text { Benda zakat tidak } \\
\text { mengalami peningkatan } \\
\text { karena dikonsumsi }\end{array}$ & $\begin{array}{lrr}\text { Benda zakat } & \text { mengalami } \\
\text { peningkatan nilai } & \text { karena } \\
\text { diproduktifkan } & & \text { sebelum } \\
\text { dikonsumsi } & & \\
\end{array}$ & - B (Produktif) \\
\hline
\end{tabular}

Perubahan dari pola zakat konsumtif ke produktif memiliki nilai kemanfaatan yang lebih tinggi pada distribusi zakat karena benda zakatnya masih tetap dan manfaatnya akan tetap didapatkan oleh mustahiq al-zakāt. Hal ini terjadi karena harta zakat tersebut telah berubah menjadi benda yang dapat diproduktifkan seperti mesin jahit atau gerobak dorong yang dapat digunakan setiap hari dalam mengais rezeki atau pendapatan. Hal ini berbeda dengan perubahan wakaf, perubahan tersebut memang diharuskan untuk mendapat manfaat dengan memastikan harta wakaf harus tetap terjaga dan tidak boleh habis.

Ketika paradigmanya hanya konsumtif biasanya hanya mempertahankan benda wakaf saja (dawām al-'ain), sementara jika diproduktifkan maka selain mempertahankan bendanya, juga mempertahankan manfaat wakaf itu (dawām al-intifā' bi al- 'ain). Untuk lebih jelasnya, berikut ini digambarkan dalam bentuk tabel (matriks).

Tabel : 3 .

Makna Perubahan Wakaf dari Konsumtif ke Produktif

\begin{tabular}{|c|c|c|c|}
\hline HAL & \multicolumn{2}{|c|}{ PERUBAHANNYA } & KETERANGAN \\
\hline Dalam Bentuk Huruf & $\Delta \Delta=$ & $\rightarrow$ 品 & - A (Konsumtif) \\
\hline Dalam Perspektif & $\begin{array}{c}\text { دَوَامُ أْلَيْنِ } \\
\text { (Tetapnya } \\
\text { Benda Wakaf) }\end{array}$ & $\begin{array}{c}\text { دوَامُ الْإنْنِفَاءِ بِالْعَيْنِ } \\
\text { (Tetapnya Manfaat } \\
\text { Benda Wakaf) }\end{array}$ & - B (Produktif) \\
\hline
\end{tabular}

Selo Soemardjan menjelaskan bahwa perubahan sosial adalah segala perubahan pada lembaga kemasyarakatan di dalam suatu masyarakat yang mempengaruhi sistem sosialnya, termasuk di dalamnya nilai-nilai, sikapsikap, dan pola-pola perilaku di antara kelompok masyarakat. ${ }^{39}$ Jika diperhatikan makna perubahan sosial menurut Selo Soemardjan di atas, maka akan tergambar bahwa perubahan menuju pengelolaan zakat dan wakaf secara produktif akan mempengaruhi sikap, pola, dan perilaku umat Islam dalam mengelola zakat dan wakaf.

Pada akhirnya terjadilah perubahan norma masyarakat sehingga melahirkan proses integrasi dari pengelolaan secara konsumtif menuju pengelolaan secara produktif. Hal ini terjadi karena inti perubahan masyarakat adalah perubahan norma-norma masyarakat. Perubahan norma dan proses pembentukan norma baru merupakan inti dari usaha mempertahankan persatuan hidup kelompok, dengan sendirinya 
proses perubahan masyarakat menjadi proses integrasi dalam banyak bidang.

Dengan melihat makna perubahan zakat dan wakaf menuju pengelolaan secara produktif dapat dilihat dari perbedaannya sebagaimana tergambar pada uraian di awal. Secara detail dapat tergambar bahwa perbedaan zakat produktif dan wakaf produktif di Indonesia dapat dilihat dari lima hal, yakni dasar hukum, orang yang mengeluarkan (wāqif dan muzakkī), hartanya (mawqūf bih dan mal al-zakat), pengelola (nāzir dan 'āmil), dan yang berhak menerima (mauqūf 'alaih dan mustahiq).

Kelima hal ini menunjukkan adanya perbedaan dan persamaan antara zakat dan wakaf. Perbedaannya bahwa (1) zakat disebutkan secara tegas dan jelas dalam nașs, sementara wakaf secara tidak tegas; (2) muzakki-nya wajib mengeluarkan zakat jika telah memenuhi syarat, muzakki tidak bisa menentukan syarat tertentu kecuali sesuai dengan syarā', sementara wakif mengeluarkan wakaf hanya karena anjuran, wakif dapat menentukan syarat-syarat asal tidak bertentangan dengan syarā'; (3) harta zakat boleh dibagikan langsung harta zakatnya, sementara harta wakaf tidak boleh dibagikan langsung harta wakafnya, kecuali hasilnya saja; (4) àmil secara tegas disebutkan dalan nașs alQur'an (Qs. al-Taubah: 60), sementara pada wakaf nāzir bukan merupakan rukun dari wakaf; (5) sasaran zakat sudah pasti pada delapan kelompok, sementara sasaran wakaf ditujukan kepada kebajikan dan lebih luas dari peruntukan zakat.

Adapun persamaannya adalah (1) memiliki dasar hukum; (2) mengeluarkan harta untuk kepentingan kebajikan; (3) dapat dinikmati bahkan dimiliki oleh pihak yang berhak menerima; (4) memerlukan pengelola agar dapat terdistribusi dengan baik sesuai syarak.

Dengan demikian, di balik perbedaannya itu ternyata antara zakat dan wakaf merupakan dua hal yang saling melengkapi, sebab kalau hanya mengandalkan zakat sebagai pemberian wajib saja, maka tidak akan memberikan dampak yang menyeluruh dalam menyelesaikan persoalan ekonomi umat. Maka ketika aset zakat dirasa masih kurang karena misalnya tidak dikelola dengan maksimal, maka kehadiran institusi wakaf diharapkan dapat mengurangi kelemahan yang ada pada zakat.

Zakat produktif dan wakaf produktif dianggap sebagai bagian dari perubahan hukum Islam di Indonesia karena keduanya merupakan filantropi Islam yang senantiasa mengalami perkembangan dari masa ke masa. Hal ini dapat disebabkan oleh berbagai faktor. Robertson $^{40}$ menyebutkan, ada beberapa faktor yang menyebabkan terjadinya perubahan sosial, yakni (a) perkembangan pembangunan fisik (the physical environment), (b) perubahan budaya (cultural innovation) yang terdiri dari penemuan (discovery), penciptaan (invention), dan penyebaran (diffusion), (c) pertumbuhan penduduk (population), (d) teknologi baru (technology), (e) perbuatan manusia (human action), yang terdiri dari perbuatan individu (individual action) dan perbuatan kelompok (collective action).

Perkembangan pengelolaan zakat dan wakaf secara produktif di Indonesia lebih banyak disebabkan oleh faktor perkembangan pembangunan fisik dan perkembangan teknologi baru atau iptek. Hal ini dapat dilihat dari semakin canggihnya pengelolaan berbagai kebutuhan manusia terutama dalam hal perdangangan. Ini pula yang ikut mempengaruhi institusi zakat dan wakaf yang merupakan institusi harta umat ( $m \bar{a} l$ al-ijtimā'iyyah) untuk dikembangkan secara produktif dan berkesinambungan.

Sementara menurut Rakhmat, ${ }^{41}$ dalam masyarakat perubahan sosial atau lebih tepatnya rekayasa sosial disebabkan oleh: (a) perubahan ide, pandangan hidup 
dan dunia, serta nilai-nilai; (b) munculnya tokoh-tokoh besar; (c) adanya gerakangerakan sosial, termasuk Lembaga Swadaya Masyarakat (LSM) dan yayasan. Dengan demikian, perubahan zakat dan wakaf ini menuju pengelolaan secara produktif lebih banyak disebabkan karena perubahan idea dan pandangan hidup, dan adanya gerakan-gerakan sosial, baik yang dilakukan oleh lembaga sosial seperti Tabung Wakaf Indonesia (TWI) maupun oleh Kemenag RI sendiri.

Kalau pada masa lampau zakat dikelola secara konsumtif saja sudah dianggap cukup, demikian juga wakaf dikelola seadanya, tetapi saat ini dengan perkembangan Iptek dan kemajuan pembangunan dalam segala lini menghajatkan zakat dan wakaf dikelola secara lebih maslahat untuk menambah nilai manfaat kedua institusi ini.

Saat ini diakui atau tidak masyarakat muslim masih pro-kontra tentang pengelolaan zakat dan wakaf secara produktif ini. Ada di antara umat Islam yang masih ragu jika zakat dan wakaf dikelola secara produktif itu akan serta merta meningkatkan nilai manfaat kedua institusi ini. Oleh karena itu, perubahan paradigma dan pandangan (mindset) umat Islam mutlak diperlukan sehingga perubahan sosial dalam hal ini merupakan hal yang tidak terbantahkan.

\section{G. Penutup}

Berdasarkan pembahasan di atas dapat disimpulkan beberapa hal: pertama, perbedaan zakat produktif dan wakaf produktif di Indonesia dapat dilihat dari lima hal, yakni dasar hukum, orang yang mengeluarkan (wāqif dan muzakkīi), hartanya (mauqūf bih dan māl al-zakāt), pengelola (nāzir dan 'āmil), yang berhak menerima (mauqūf 'alaih dan mustahiq). Kelima hal ini menunjukkan adanya perbedaan dan persamaan antara zakat dan wakaf, di antaranya kedua-duanya sama-sama merupakan filantropi Islam yang memiliki visi pemerataan harta dan pengentasan kemiskinan. Perbedaannya, zakat selain bersifat wajib juga dapat didistribusikan harta zakat secara langsung. Sementara, selain sifat wakaf itu anjuran (sunnat), yang dapat didistribusikan adalah hasilnya dan tidak boleh bendanya karena harus ditahan kelestariannya.

Kedua, zakat produktif dan wakaf produktif dapat disebut sebagai bagian dari perubahan hukum Islam di Indonesia karena keduanya merupakan filantropi Islam yang senantiasa mengalami perkembangan. Istilah produktif dalam kedua filantropi tersebut sebenarnya bukan merupakan hal yang sangat baru. Jika dilihat dari sisi etimologinya, zakat berarti bertambah. Muncul istilah zakat produktif hanya bersifat penegasan kembali. Lebih-lebih lagi wakaf, institusi ini bahkan memiliki semangat utama untuk dikembangkan karena yang bisa didistribusikan hanya hasil dari produktivitas itu. Bedanya, kalau zakat dapat didistribusikan langsung tanpa diproduktifkan, maka wakaf harus diproduktifkan dahulu baru dapat didistribusikan hasilnya, kecuali wakaf langsung seperti masjid.

Ketiga, bentuk perubahan sosial yang diharapkan sehingga zakat dan wakaf perlu dikembangkan secara produktif adalah perubahan pada aspek pemahaman zakat dan wakaf yang sebelumnya hanya konsumtif menjadi zakat dan wakaf yang produktif. Selanjutnya perubahan pemahaman itu diharapkan dapat diaplikasikan pada perubahan praktik sehingga dapat tersalurkan zakat dan wakaf secara produktif yang memiliki kemanfaatan lebih banyak. 


\section{Catatan Akhir:}

1 Berkaitan dengan kata produktif, Imamuddin Yuliadi menjelaskan bahwa produksi diartikan dengan kegiatan ekonomi yang dapat meningkatkan nilai tambah suatu barang. Pengertian produksi tidak hanya diartikan dengan proses perubahan dari input menjadi output saja tetapi pengertian produksi menyangkut peningkatan nilai tambah suatu barang. Produksi bisa diartikan dengan perubahan bentuk suatu barang disebut form utility, memindahkan tempat penggunaan barang disebut place utility, menyimpan barang untuk dimanfaatkan disebut time utility, dan perpindahan kepemilikan suatu barang disebut possesion utility. Imamudin Yuliadi, Ekonomi Islam: Sebuah Pengantar (Yogyakarta: LPPI, 2001), hlm. 192.

2 Achmad Djunaidi (ed.), Paradigma Baru Wakaf di Indonesia (Jakarta: Direktorat Zakat dan Wakaf RI, 2005), hlm., v-vi.

3 Dalam hal perubahan, J. Winardi mengatakan bahwa manusia perlu senantiasa berubah sesuai dengan tuntutan perubahan itu sendiri. Perubahan yang dimaksud meliputi misalnya perubahan dalam perilaku, perubahan dalam sistem nilai dan penilaian, perubahan dalam metode dan cara-cara bekerja, perubahan dalam peralatan yang digunakan, perubahan dalam cara berpikir, perubahan dalam hal bersikap. J. Winardi, Manajemen Perubahan (Management of Change) (Jakarta: Kencana, 2006), hlm. 1.

${ }^{4}$ Berikut ini adalah kaidah yang terkait dengan perubahan hukum Islam:

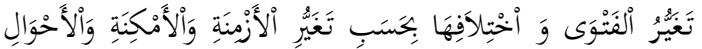

$$
\begin{aligned}
& \text { وَالنِّيَّاتِ وَأْلَوََائدِدِ }
\end{aligned}
$$

"Berubah dan berbedanya fatwa sesuai dengan perubahan zaman, tempat, kondisi sosial, niat, dan adat kebiasaan". Nasrun Haroen, Perdagangan Saham di Bursa Efek Tinjauan Hukum Islam (Jakarta: Yayasan Kalimah, 2000), hlm. 34-35.

5 Hal senada dikatakan oleh M. Atha' Mudzhar bahwa kenyataan sejarah perjalanan Hukum Islam ternyata membawa faktor sosial budaya yang telah mempengaruhi produk-produk pemikiran hukum Islam, baik yang berbentuk kitab fiqih, Undang-Undang, Keputusan Pengadilan, dan fatwa-fatwa ulama'. M. Atha' Mudzhar, Membaca Gelombang Ijtihad: Antara Tradisi dan Liberasi (Yogyakarta: Titian Ilahi Press., 2008), hlm. 127. Hal senada juga diungkapkan oleh Ridwan as-Sayyid dan M.Quraish Shihab bahwa dalam suatu peristiwa selalu terdapat tiga unsur, yakni (a) peristiwa yang terjadi, (b) pelaku, dan (c) waktu. Dewan Redaksi, Ensiklopedi Hukum Islam, hlm. 136.
${ }^{6}$ Menurut Isa Abduh, ibādah mahdah adalah ibadah yang murni kepada Tuhan (seperti salat). Termasuk ibadah mahḍh ini adalah rukun Islam yang lima. Isā 'Abdūh, An-Nazm alMāliyah fì al-Islām (Kairo: Ma'had ad-Dirasat alIslamiyah, 1396-1397 H.), hlm. 163.

7 A. Hassan menegaskan bahwa ayatayat tentang ubūdiyyah ini tidak perlu diselidiki makna dan maksudnya. Sifat dari ranah ini adalah tertutup dari kreasi manusia (gayr ma'qūl al$m a$ 'na). Sedangkan ayat-ayat tentang mu'āmalah adalah ayat-ayat hukum yang ditetapkan untuk mengatur hubungan perorangan dan hubungan masyarakat. Ayat-ayat tentang mu'āmalat ini bersifat terbuka dan dapat dimengerti ( $m a$ 'qūl alma'nâ)". Ahmad Hassan, Tafsīr al-Furqān (Bangil: Persatuan, tth.), hlm. xxv.

8 Dalam bahasa Arab, kaidah tersebut berbunyi:

$$
\text { الأصل فن العبادة التوقيف والإتباع }
$$

$\begin{array}{rccc}\text { Lihat } & \text { Ibnu } & \text { Taimiyyah } & \text { (Juz II, } \\ \text { 1422H/2001: } & \text { 306). } & \text { Ibnu } & \text { Taimiyyah }\end{array}$ mengungkapkan dengan kata-kata: "anna al'ibādah allati aujabahā Allāh la yaśbutu al-amr illā bi asy-syar'i'". Berkaitan dengan ibadah, dalam kitab al-Bayān, Hakim (1358/1939: 215) mengutip kaidah yang bunyinya: "al-Aṣlu fi alibādah al-butlān hatta yaqūma dalīlun 'alā alamri"

9 Dalam bahasa Arab, kaidah tersebut berbunyi:

$$
\text { الأصل في المعاملة الإباحة حتى يدل الدليل على تحريمها }
$$

Muhamad bin Ali al-Syaukāni, al-Dirār alMuḍiyah Syarh al-Durār al-Bahiyyah (Beirut: Mu'assasah al-Kutub al-Tsaqafah, 1988), hlm. 284-285 dan Haroen, Perdagangan, hlm. 8-9.

${ }^{10}$ Lihat Tim Bank Indonesia (2005), hlm. 4

${ }^{11}$ Ahmad Rofiq, Pembaharuan Hukum Islam di Indonesia (Yogyakarta: Gama Media, 2001), hlm. 20.

${ }^{12}$ Ibid., hlm. 20.

${ }^{13}$ Ibid., hlm. 2.

${ }^{14}$ Undang-Undang No. 23 tahun 2011

tentang Pengelolaan Zakat

15 M. Daud Ali, Sistem Ekonomi Islam, Zakat dan Wakaf (Jakarta: UI-Press, 1998), hlm. 62.

${ }^{16}$ Menurut Abu Hanifah: "Wakaf adalah menahan bendanya (wakaf) dengan ketentuan harta itu tetap dalam kepemilikan wakif, dan mensadaqahkan manfaatnya pada jalan kebaikan." Menurut Abu Hanifah, wakaf tidak mengharuskan hilangnya hak kepemilikan bagi wakif, bagi Abu Hanifah adalah wakaf itu hukumnya boleh dan bersifat gair lāzim (tidak tetap). Menurut jumhur Ulama: "Wakaf adalah 
menahan harta yang dapat dimanfaatkan tanpa lenyap bendanya, dengan cara tidak melakukan tindakan hukum terhadap benda tersebut, disalurkan pada sesuatu yang mubah (tidak haram) yang ada." Menurut Malikiyah: "Wakaf adalah pemilik harta menjadikan manfaat dari suatu barang yang dimiliki walaupun kepemilikan itu dengan cara sewa atau dengan menjadikan kepemilikannya itu berupa hasilnya seperti dirham (mata uang), yang diperuntukkan bagi orang yang berhak menerimanya dengan menggunakan sigat tertentu selama waktu yang sesuai menurut pandangan orang yang memegang harta wakaf itu." Menurut Malikiyah, wakaf tidak harus kekal (ta'bìd). Wahbah al-Zuhayli, alWasāya wa al-Waqf fì al-Fiqh al-Islāmiy (Damsyiq: Dār al-Fikr, 2007), hlm. 133-135.

Abdullah Sa'ad al-Hajiri, Taqyīm Kafā'at Istis̄mār Amwāl al-Auqāf b̄ Daulat alQuwait (Kuwait: al-Amānah al-Āmmah lī alAuqāf Idārat ad-Dirāsat wa al-Alāqat alKhārijiyyah, 2006), hlm. 30.

18 Jaih Mubarok, Wakaf Produktif

(Bandung: Simbiosa Rekatama Media, 2008), hlm. 15-16.

19 Monzer Qahaf, al-Waqf al-Islāmî: Tatawwuruh Idāratuh wa Tanmiyatuh (Damaskus: Dār al-Fikr, 2000), hlm. 159.

${ }^{20} \mathrm{KH}$. Tolhah Hasan, "Wawasan Umum tentang Waqaf dan Pengelolaannya di Era Modern", Slide Bahan Ajar S3 IAIN Walisongo, 2010, hlm. 2-3.

21 Penjelasan pasal ini berbunyi: "Pengelolaan dan pengembangan harta benda wakaf dilakukan secara produktif antara lain dengan cara pengumpulan, investasi, penanaman modal, produksi, kemitraan, perdagangan, agrobisnis, pertambangan, perindustrian, pengembangan teknologi, pembangunan gedung, apartemen, rumah susun, pasar swalayan, pertokoan, perkantoran, sarana pendidikan ataupun sarana kesehatan, dan usaha-usaha yang tidak bertentangan dengan syariah."

${ }^{22}$ Mustafa Edwin Nasution dan Uswatun Hasanah, Wakaf Tunai, Inovasi Finansial Islam, Peluang dan Tantangan dalam Mewujudkan Kesejahteraan Umat (Jakarta: PSTTI-UI, 2005), hlm. 1-2.

23 Al-Bukhārī, Șah̄ịh al-Bukhārī (Kairo: Rayyan, 1986), X: 87, 153; XXII: 169; Hadis ini dengan redaksi yang sedikit berbeda dapat pula ditemukan di dalam Sunan Abi Dawud bab Wasāya, hadis 13, Șaḥị̣ Muslim, bab al-Waqf, hadis 1232, Sunan Turmuzi, fì al-Ahkām 'an Rasūlillāh fi al-Waqf, ḥadis 1296, dan Sunan Nasāi, fī al-Aḥbās, ḥadis 3541 .

24 Achmad Junaidi, Paradigma Baru Wakaf di Indonesia (Jakarta: Direktorat
Pemberdayaan Wakaf Dirjen Bimas Depag RI, 2008), hlm. 23.

${ }^{25}$ Ibid., hlm. 37.
${ }^{26}$ Ibid., hlm. 39-40.
${ }_{28}$ Ibid., hlm. 40-42.
${ }_{28}$ Al-Kabisi me

28 Al-Kabisi menjelaskan bahwa distribusi harta wakaf diperuntukkan bagi sasaran tertentu dengan syarat-syarat: (a) sasaran itu berupa salah satu bentuk kebajikan, (b) di dalamnya tidak terdapat maksiat, (c) tidak bertentangan dengan aturan hukum, (d) aktivitas kebajikan dalam sasaran wakaf hendaknya bersifat kontinyu, (e) barang yang diwakafkan tidak kembali kepada si wakif, (f) pihak yang diberi wakaf cakap hukum untuk menguasai harta wakaf. Muḥammad 'Ābid Abdullāh al-Kabisi, Hukum Wakaf, terj. Ahrul Tsani Fathurrahman dkk.(Jakarta: Dompet Dhuafa Republika dan IlMan Press, 2004), hlm. 284.

${ }^{29}$ M. Fuad Nasar, "Integrasi Pengelolaan Zakat dalam UU No 23 Tahun 2011", September 11, 2012 4:51 pm.

${ }^{30}$ Ibid.

${ }^{31}$ Muslihun, "Menuju Wakaf Produktif: Studi Pergeseran Pemahaman Wakaf Tuan Guru tentang Wakaf di Lombok", Disertasi S3 IAIN Walisongo Semarang, 2012, hlm. 156.

${ }^{32}$ Ibid., hlm. 157.

${ }^{33}$ Muslihun Muslim, Fiqh Ekonomi dan Positiviasasinya di Indonesia (Mataram: LKIM IAIN Mataram, 2005), hlm. 126.

${ }^{34}$ H. Suparman Usman, Hukum Islam: Asas-Asas dan Pengantar Studi Hukum Islam dalam Tata Hukum Indonesia (Jakarta: Gaya Media Pratama, 2001), hlm. 163.

${ }^{35}$ Mustafa Edwin Nasution dan Uswatun Hasanah, Wakaf Tunai,hlm.2.

36 Memberdayakan wakaf secara produktif dapat ditelusuri dari karakteristik kata pemberdayaan itu sendiri. Secara bahasa, kata pemberdayaan berasal dari kata daya. Daya artinya power (kekuatan). Pemberdayaan (empowerment) adalah proses seseorang, organisasi, dan masyarakat mampu mengurus kebutuhan dan permasalahannya sendiri, sehingga peduli terhadap diri dan lingkungannya. Mukmin, "Peranan Pondok Pesantren dalam Pemberdayaan Masyarakat dan Pemdes", Makalah pada RKKP PW NW NTB, tanggal 17-18 Juli 2009 di Mataram.

${ }^{37}$ Jaih Mubarok, Wakaf, hlm.16.

${ }^{38}$ Hendrojono, Sosiologi Hukum: Pengaruh Perubahan Masyarakat dan Hukum (Surabaya: Srikandi, 2005), hlm. 41. Parsons melihat perubahan bukan sebagai suatu yang mengganggu keseimbangan sosial, tetapi sebagai sesuatu yang merubahnya, sehingga seperti menghasilkan keseimbangan yang baru dan secara mutu berbeda. Ian Robertson, Sosiology, $3^{\text {rd }}$ 
edition, Editor Peter Deane, Linda Baron Davis (New York: Worth Publishers, Inc., 1988), hlm. 518.

${ }^{39}$ Soerjono Soekanto, Sosiologi Suatu Pengantar (Jakarta: Rajawali Press.Soekanto, 2005), hlm. 305.

${ }^{40}$ Robertson, Sosiology, hlm. 508-514.

${ }^{41}$ Jalaludin Rakhmat, Rekayasa Sosial: Reformasi, Revolusi atau Manusia Besar, cet. 2 (Bandung: Rosdakarya, 2000), hlm. 50.

\section{DAFTAR PUSTAKA}

Abduh, Isa. Al-Nuzūm al-Māliyah fì alIslām. Kairo: Ma'had al-Dirāsat al-Islāmiyah, 1396-1397 H.

Ali, Muhammad Daud. Sistem Ekonomi Islam, Zakat dan Wakaf. Jakarta: UI-Press, 1998.

Al-Asyhar, Thabib, "Paradigma Baru dan Substansi Undang-Undang Wakaf", Makalah dipresentasikan pada Lokakarya Perwakafan Masyarakat Kampus 2006 di Mataram NTB., 29 Agustus 2006, Anderson, JND. Hukum Islam di Dunia Modern, Terj. Machnun Husein. Surabaya: Amar Press, 1990.

Antonio, Muhammad Syafi'i. "Pengelolaan Wakaf Secara Produktif", dalam Ahmad Djunaidi dan Thobieb al-Asyhar. Menuju Era Wakaf Produktif: Sebuah Upaya Progresif Untuk Kesejahteraan Umat. Jakarta: Mitra Abadi Press, 2005.

Badan Wakaf Indonesia (BWI). Rekomendasi Workshop Nāzir Profesional. Hotel Sofyan, Jakarta, 5-7 Agustus 2008.

Al-Bukhari, Imam. Șaḥ̄ḥ Bukhārī. Kairo: Rayyan, 1986.

Dewan Redaksi Ensiklopedi Hukum Islam. Ensiklopedi Hukum Islam. Jakarta: PT. Ichtiar Van Hoeve, 1997.

Djunaidi, Ahmad, dkk. Paradigma Baru Wakaf di Indonesia. Jakarta:
Direktorat Zakat dan Wakaf RI, 2005.

Al-Hājiriy, A.S. Taqyīm Kafā'at Istis̀mār Amwāl al-Auqā̃ bi Daulat alQuwait. Kuwait: al-Amānah alĀmmah lī al-Auqāf Idārat adDirāsat wa al-Alāqat alKhārijiyyah, 2006.

Haroen, Nasrun. Perdagangan Saham di Bursa Efek Tinjauan Hukum Islam. Jakarta: Yayasan Kalimah, 2000.

Hasanah, Uswatun. "Peranan Wakaf dalam Mewujudkan Kesejahteraan Sosial: Studi Kasus Pengelolaan Wakaf di Jakarta Selatan". Disertasi Pascasarjana IAIN Syarif Hidayatullah Jakarta, 1997.

Hassan, Ahmad. Tafsīr al-Furqān. Bangil: Persatuan, t.t.

Hendrojono. Sosiologi Hukum: Pengaruh Perubahan Masyarakat dan Hukum. Surabaya: Srikandi, 2005.

Al-Kabisi, M. A. A. Hukum Wakaf, Terj. Ahrul Tsani Fathurrahman dkk. Jakarta: Dompet Dhuafa Republika dan IIMan Press, 2004.

Mubarok, Jaih. Wakaf Produktif. Bandung: Simbiosa Rekatama Media, 2008.

Mudzhar, Muhammad Atha'. Membaca Gelombang Ijtihad: Antara Tradisi dan Liberasi. Yogyakarta: Titian Ilahi Press, 1998.

Muslihun, "Menuju Wakaf Produktif: Studi Pergeseran Pemahaman Wakaf Tuan Guru tentang wakaf di Lomnbok", Disertasi S3 IAIN Walisongo Semarang, 2012.

Muslim, Muslihun. Fiqh Ekonomi dan Positiviasasinya di Indonesia. Mataram: LKIM IAIN Mataram, 2005.

Nasution, Mustafa Edwin dan Uswatun Hasanah. Wakaf Tunai, Inovasi Finansial Islam, Peluang dan Tantangan dalam Mewujudkan 
Kesejahteraan Umat. Jakarta: PSTTI-UI, 2005.

Qohaf, Monzer. Ekonomi Islam: Telaah Analitik terhadap Fungsi Sistem Ekonomi Islam, terj. Machnun Husein. Yogyakarta: PT. Tiara Wacana, 1995.

Rakhmat, Jalaludin. Rekayasa Sosial: Reformasi, Revolusi atau Manusia Besar. Bandung: Rosdakarya, 2000.

Robertson, Ian. Sociology. Third Edition, Editor Peter Deane, Linda Baron Davis. New York: Worth Publishers, Inc., 1988.

Soekanto, Soerjono. Sosiologi Suatu Pengantar. Jakarta: Rajawali Press, 2005.
Al-Syawkāni, Muhamad bin Ali. al-Dirār al-Mudiyyah Syarh al-Durār alBahiyyah. Beirut: Mu'assasah alKutub al-Tsaqafah, 1988.

Usman, H. Suparman. Hukum Islam: Asas-asas dan Pengantar Studi Hukum Islam dalam Tata Hukum Indonesia. Jakarta: Gaya Media Pratama, 2001.

Winardi, J. Manajemen Perubahan (Management of Change). Jakarta: Kencana, 2006.

Al-Zuhayli, Wahbah. al-Wasāya wa alWaqf fi al-Fiqh al-Islāmī. Damsyiq: Dār al-Fikr, 2007. 